\title{
STUDIES ON EFFECT OF ADSORPTION PARAMETERS FOR THE METHYLENE BLUE DYE REMOVAL BY USING LOW- COST ADSORBENT
}

\author{
Ravi Vital Kandisa, Narayana Saibaba KV ${ }^{\bowtie}$, Khasim Beebi Shaik \\ and R. Gopinadh \\ Department of Biotechnology, GITAM Institute of Technology (GIT) \\ GITAM (Deemed to be University), Visakhapatnam-530045, (Andhra Pradesh) India \\ ${ }^{\square}$ Corresponding Author: kvnsai@yahoo.com
}

\begin{abstract}
The textile industry causes water pollution by releasing used wastewater into natural water sources. In the present study, naturally available adsorbent was used to study the efficiency of Methylene Blue (MB) dye removal from wastewater effluents. Three different parameters such as the effect of contact time, effect of temperature and effect of initial dye concentration on Methylene blue dye removal by using the Vigna Trilobata pod adsorbent were examined. From the experimental results it is proved that the dye removal efficiency of naturally available Vigna Trilobata pod is effective and can be alternative to commercially available adsorbents used for removal of Methylene Blue dye from industrial wastewater.

Keywords: Wastewater Treatment, Adsorption, Dye Removal, Methylene Blue, Effect of Parameters, Vigna Trilobata Pod, Adsorption Capacity
\end{abstract}

RASĀYAN J. Chem., Vol. 14, No.2, 2021

\section{INTRODUCTION}

Dyes are used in various industries such as textile, leather, paper, plastic and pharmaceuticals ${ }^{1,2}$ etc. Dyes are the major water pollutants in the textile industry that contaminate water sources. Release of colored wastes such as dyes and pigments into the natural water bodies by textile industries can lead to environmental pollution. ${ }^{3,4}$ Apart from the color, some dyes impart invisibility and can be changed biologically to toxic compounds. Textile industry dyes are showing long-term toxic effects with dissolved pollutants $^{3}$. Release of textile industry colored and polluted wastewater into the natural water resources like ponds, reservoirs and rivers lead to high impact on the environment as well as on human health. ${ }^{5}$ There are various methods available such as physical, chemical and biological treatment methods, for the dye removal process from textile industry wastewater.,

From the earlier studies, adsorption was found as an economically low-cost and efficient method to remove pollutants such as dyes and metal impurities from industrial waste water. ${ }^{8}$ Few of the adsorbent materials like rice husk, almond shell, date pits, charcoal, apricot stone, prawn shell, neem peel, wood apple shell, palm kernel fiber, oil palm wood, sawdust, Abelmoschusesculentus (lady's finger), kaolin, chitosan, potato stem powder, coal fly ash, soya bean oil cake, ${ }^{9}$ banana peel, bamboo leaves ash, pure lignin, sugar cane bagasse, wheat straw, coconut husk, groundnut shell, ${ }^{10}$ lotus leaf and wood were successfully used for various dye removal processes from aqueous solutions. More than 100,000 dyes are commercially available like acid, basic, fluorescent, reactive, metal complex, direct, and sulphur dyes. ${ }^{11}$

Studies proved that short periods of exposure to MB dye leads to severe health issues such as Jaundice, increased heart rate, tissue necrosis, breathing, eye burns, nausea, and vomiting etc. ${ }^{11-15}$ The present study deals with Methylene blue (MB) which was found to be the most commonly used dye in textile industries ${ }^{16}$ Adsorption is one of the simple and cost-effective techniques used to remove the effluents from textile industry waste water. ${ }^{17,18}$ Aim of the current study is to evaluate the low cost naturally available biosorbent efficiency and adsorption capacity in the removal of Methylene blue from aqueous solutions. Effect of initial dye concentration, the effect of contact time and the effect of temperature on 
RASĀYAN J. Chem.

Vol. 14 | No. 3 |1528-1533| July - September | 2021

Methylene blue adsorption were examined to optimize the conditions leading to maximum removal efficiency of Methylene blue dye from textile industry wastewater.

\section{EXPERIMENTAL}

\section{Adsorbent}

Vigna Trilobata Pod was collected from Martur village in Vishakhapatnam District, India and used as an adsorbent in this study. It was collected from natural sources and washed thoroughly under the running tap, followed by distilled water until the dust particles were removed from the adsorbent. The adsorbent was dried in sunlight for 48 hours, grounded and screened through a set of sieves to obtain particles of different sizes and the sieved powder was kept dry in a closed container. It was ensured that there was no color produced by Vigna Trilobata Pod when it was in contact with the dye solution.

\section{Adsorbate}

Methylene blue (MB) dye was purchased from Sigma-Aldrich a chemicals company, $1.0 \mathrm{~g}$ of MB was added to $1000 \mathrm{ml}$ of distilled water to prepare the stock solution of Methylene blue dye and it was further diluted to prepare the test solutions of various required concentrations $(25 \mathrm{mg} / \mathrm{L}-150 \mathrm{mg} / \mathrm{L})$. Molecular structure of the Methylene blue is shown in Fig-1.<smiles></smiles>

\section{Adsorption Experiments}

Fig-1: Molecular Structure of Methylene blue (MB)

Adsorption experiments were conducted in a batch process. Effect of various adsorption parameters such as the effect of contact of time, the effect of initial dye concentration and the effect of temperature were studied. $0.2 \mathrm{~g}$ of Vigna Trilobata pod was added to $50 \mathrm{ml}$ of MB stock solutions of known concentrations taken in a set of $250 \mathrm{ml}$ Erlenmeyer flasks. All the flasks were kept in an orbital shaker at various time intervals and different temperature conditions. All the samples were taken from an orbital shaker and kept in centrifugation at $4000 \mathrm{rpm}$ for $10 \mathrm{~min}$. Final concentrations of supernatant were examined by using UV Spectrophotometer at a maximum wavelength of $665 \mathrm{~nm}$ to find the dye concentration in the aqueous solution. The amount of dye ( $\mathrm{mg} / \mathrm{g})$, adsorbed by Vigna Trilobata pod can be represented by the following equation:

$$
q_{e}=\left\lceil\frac{\left(C_{0}-C_{e}\right) V}{m}\right\rceil
$$

Where $C_{0}$ is the initial MB concentration and $C_{\boldsymbol{e}}$ is the MB dye concentration at equilibrium in $\mathrm{mg} / \mathrm{L}, V$ is volume of dye solution (L) and $m$ is mass of the adsorbent (g) used.

Methylene blue removal efficiency in percentage (\%) can be represented by the following equation: ${ }^{19-27}$

$$
\% \text { MB Removal }=\left[\frac{C_{o}-C_{e}}{C_{o}} \times 100\right]
$$

Where, $C_{0}$ is initial $\mathrm{MB}$ concentration and

$C_{e}$ is MB dye concentration at equilibrium state in $\mathrm{mg} / \mathrm{L}$

\section{Effect of Contact time}

The effect of contact time on MB dye solution removal was studied using adsorbent Vigna Trilobata Pod. $50 \mathrm{ml}$ of MB dye solution with $25 \mathrm{ppm}$ concentration was taken in a $250 \mathrm{ml}$ capacity of Erlenmeyer flask 
RASĀYAN J. Chem.

Vol. 14 | No. 3 |1528-1533| July - September | 2021

and $\mathrm{pH}$ was adjusted to 7 by using $0.1 \mathrm{~N} \mathrm{NaOH}$ or $0.1 \mathrm{~N} \mathrm{HCl}$. The temperature was maintained at $30^{\circ} \mathrm{C}$ and $0.2 \mathrm{~g}$ of Vigna Trilobata Pod was added to the flask contained aqueous solution. The same procedure was followed to the remaining flasks of $50 \mathrm{ppm}, 75 \mathrm{ppm}, 100 \mathrm{ppm}, 125 \mathrm{ppm}$ and $150 \mathrm{ppm}$. All the flasks were placed in an orbital shaker for 0-120 minutes to calculate adsorption capacity (Q) and Percentage removal at various time intervals. All the sample flasks were removed from the orbital shaker and centrifuged for 10 minutes at $4000 \mathrm{rpm}$. The final concentration of the supernatant was measured by using a UV-Visible Spectrophotometer at the maximum wavelength $(665 \mathrm{~nm})$. The effect of contact time on MB removal percentage and adsorption capacity of adsorbent were determined from the results.

\section{Effect of Temperature}

Temperature has a significant effect on the rate of adsorption. $0.2 \mathrm{~g}$ of Vigna Trilobata pod was added to $50 \mathrm{ml}$ of $25 \mathrm{ppm}$ concentration MB dye solution in $250 \mathrm{ml}$ Erlenmeyer conical flask and $\mathrm{pH}$ was adjusted by using $0.1 \mathrm{~N} \mathrm{NaOH}$ or $0.1 \mathrm{~N} \mathrm{HCl}$. The experiment was conducted at different temperatures of $20-50^{\circ} \mathrm{C}$ respectively for 90 minutes (equilibrium) at $150 \mathrm{rpm}$ in an orbital shaker. After that sample solutions were centrifuged for 10 minutes at 4000rpm. The final concentration of the supernatant was measured by using a UV-Visible Spectrophotometer at the maximum wavelength $(665 \mathrm{~nm})$. The same procedure was repeated for 50-150ppm MB dye solutions. The effect of temperature on MB removal percentage and adsorption capacity of adsorbent were determined from the results.

\section{Effect of Initial Dye Concentration}

The effect of initial dye concentration can be studied by using a mixture of adsorbent- adsorbate solution. The experiment was carried out by using various dye concentrations ranging from 25-150ppm and keeping other parameters such as temperature, $\mathrm{pH}$ and time constant. All the flasks were placed in an orbital shaker for 90 minutes at $150 \mathrm{rpm}^{25}, 28-30$. The reaction mixture was taken and subjected to centrifugation for 10 minutes at 4000rpm. The supernatant was analyzed by using UV-Spectrophotometer at $665 \mathrm{~nm}$. The effect of initial dye concentration on MB removal percentage and adsorption capacity of adsorbent were determined from the results.

\section{Effect of Contact Time}

\section{RESULTS AND DISCUSSION}

Effect of contact time on MB dye removal efficiency (\%) of Vigna Trilobata pod was observed from Fig.2. There is an increase in dye removal efficiency of Vigna Trilobata pod with an increase in contact time from 0-50 minutes and remains constant up to 120 minutes to attain equilibrium. Maximum dye removal of $93.3 \%$ was achieved at $25 \mathrm{ppm}$ of dye concentration. It was observed that a slight increase of dye uptake was observed initially due to the presence of active sites on the surface of the adsorbent. Then the process becomes slow due to less availability of active sites on the Vigna Trilobata pod until equilibrium state was achieved, indicating the dependence of the adsorption process on contact time. It was observed from Fig.-3 adsorption capacity Q ( $\mathrm{mg} / \mathrm{g})$ of dye increased with an increase in initial concentration from $6.5-30.2 \mathrm{mg} / \mathrm{g}$. This indicates the availability of adsorption sites in the initial stage and the adsorption capacity increased with an increase in concentration gradient at higher initial dye concentration. Results showed that Vigna Trilobata pod is a capable adsorbent for the removal of Methylene blue dye from textile industry wastewater depending on the initial concentration.

\section{Effect of Temperature}

Graph was plotted between percent removal of dye and temperature by keeping other parameters constant as shown in Fig.-4. It was observed that there was a decrease in the percentage removal of dye when the temperature increased from $20^{\circ} \mathrm{C}$ to $50^{\circ} \mathrm{C}$. $\mathrm{MB}$ dye removal efficiency was decreased with an increase in temperature and the maximum removal efficiency was achieved at $20^{\circ} \mathrm{C}$. Results showed that there was a good interaction between Methylene blue and Vigna Trilobata pod. A decrease in removal efficiency with an increase in temperature showed that the process is exothermic.

As shown in Fig.-5, the graph was plotted between adsorption capacity (Q) and temperature. It was observed that there was a decrease in adsorption capacity of Vigna Trilobata pod with an increase in temperature which may supports physisorption. 
RASĀYAN J. Chem.

Vol. 14 | No. 3 |1528-1533| July - September | 2021

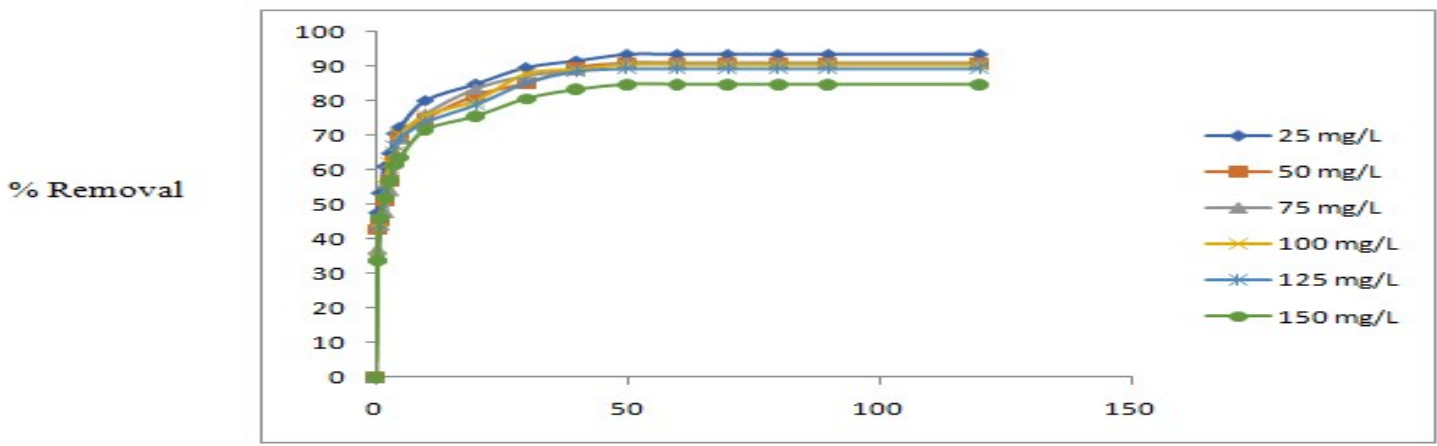

Time (min)

Fig.-2: Effect of Contact Time on Removal Efficiency (\%) of Methylene Blue by Vigna Trilobata pod

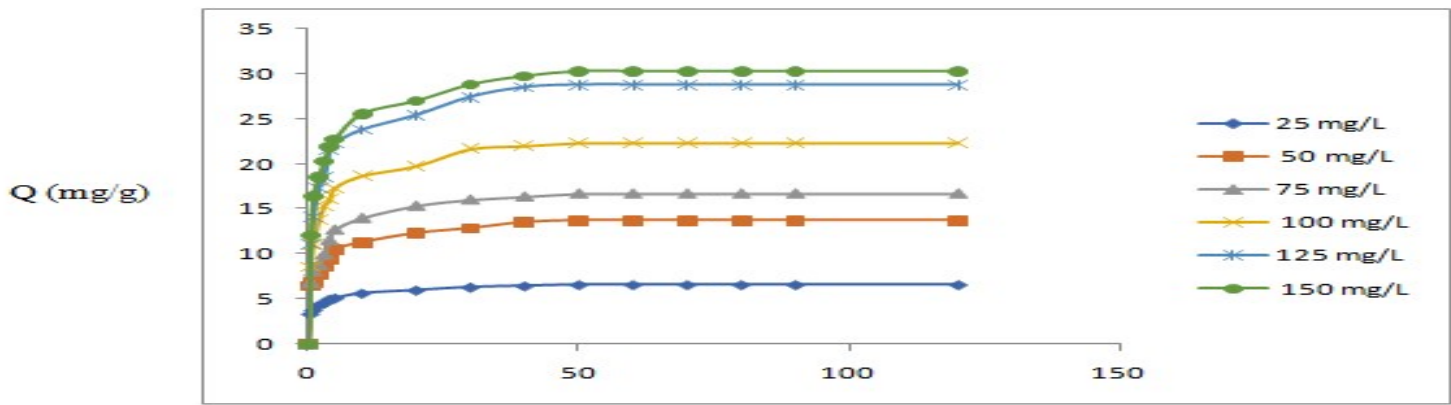

Time (min)

Fig.-3: Effect of Contact Time on Adsorption Capacity ( $\mathrm{mg} / \mathrm{g}$ ) of Methylene Blue by Vigna Trilobata pod

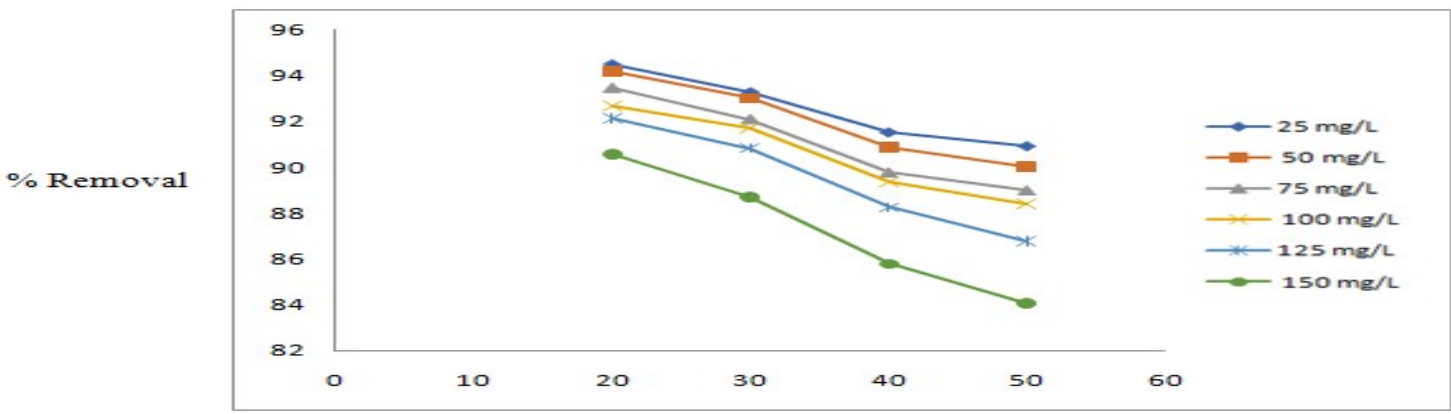

Temperature $\left({ }^{\circ} \mathrm{C}\right)$

Fig.-4: Effect of Temperature on Removal Efficiency (\%) of Methylene Blue by Vigna Trilobata pod

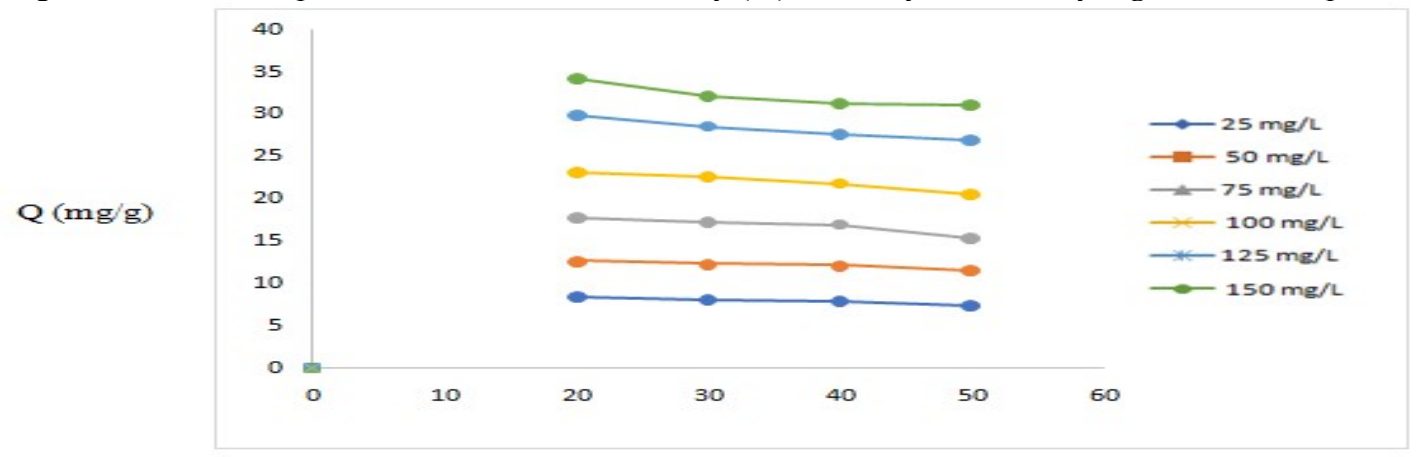

Temperature ( $\left.{ }^{\circ} \mathrm{C}\right)$

Fig.-5: Effect of Temperature on Adsorption Capacity (mg/g) of Methylene Blue by Vigna Trilobata pod 
RASĀYAN J. Chem.

Vol. 14 | No. 3 |1528-1533| July - September | 2021

\section{Effect of Initial Dye Concentration}

As shown in the graph, it was observed in Fig.-6, the amount of Methylene blue removal was dependent on initial concentration. Increased in \% removal of Methylene blue was achieved at lower concentration of MB dye. The removal efficiency (\%) was decreased from $94.5 \%$ to $90.5 \%$ with an increase in initial dye concentration. Results indicate that available adsorption sites became few at higher concentrations; indicating that the percent removal of MB is dependent on initial dye concentration.

Figure-7 represents the adsorption capacity (Q) vs initial dye concentration of dye. Adsorption capacity (Q) at equilibrium was increased from 8.4 to $34.2 \mathrm{mg} / \mathrm{g}$ with an increase in initial dye concentration from $25 \mathrm{ppm}$ to $150 \mathrm{ppm}$. Adsorption capacity depends on initial concentration as the available adsorption sites of Vigna Trilobata pod became fewer at higher dye concentrations.

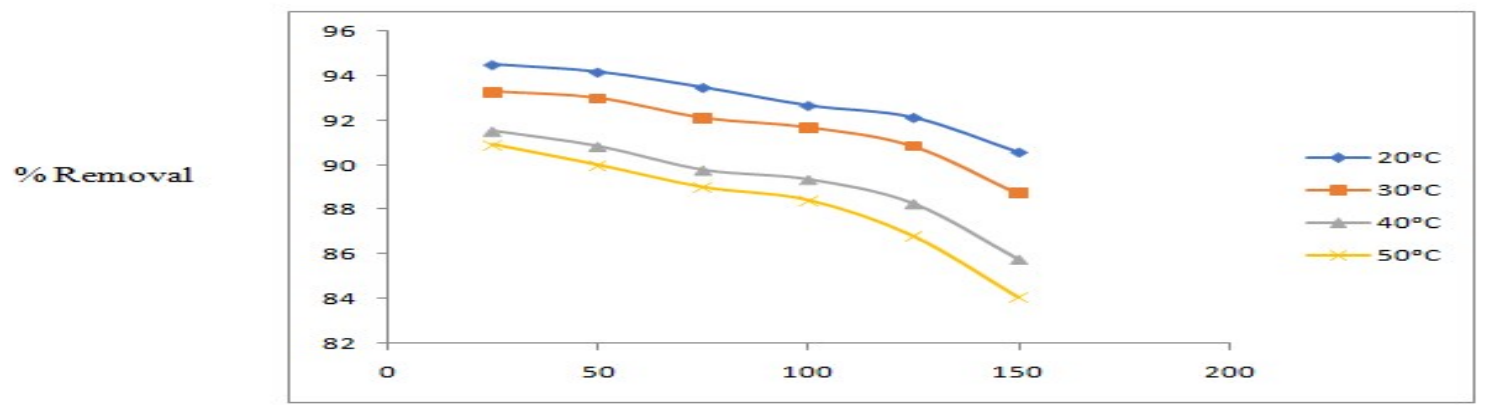

Initial concentration $(\mathrm{mg} / \mathrm{L})$

Fig.-6: Effect of Initial Concentration on Removal (\%) of Methylene Blue by Vigna Trilobata pod

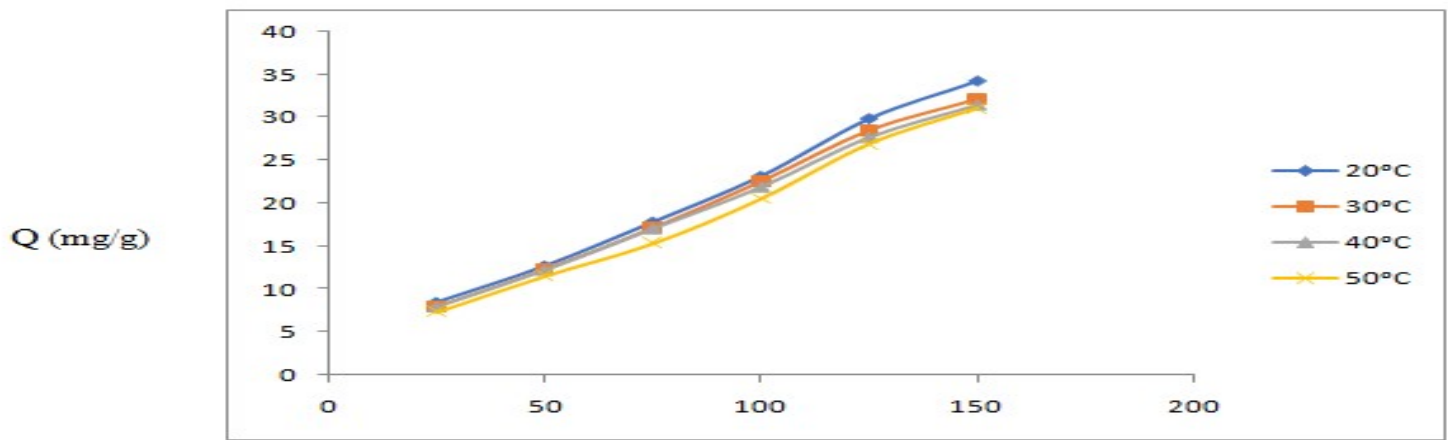

Initial concentration $(\mathrm{mg} / \mathrm{L})$

Fig.-7: Effect of Initial Concentration on Adsorption Capacity (mg/g) of Methylene Blue by Vigna Trilobata pod

\section{CONCLUSION}

Removal efficiency (\%) and adsorption capacity (Q) of Vigna Trilobata pod on Methylene blue (MB) dye removal was studied by using three different parameters such as the effect of contact time, effect of temperature and effect of initial dye concentrationn. From the results of this study, optimum removal of Methylene blue dye was observed in $50 \mathrm{~min}$ and adsorption capacity (Q) decreased with increase in temperature and Maximum MB dye removal was observed at $20^{\circ} \mathrm{C}$. Based on the results it was concluded that Vigna Trilobata pod can be used as an effective adsorbent for the rremoval of basic dyes from textile industry wastewater.

\section{REFERENCES}

1. R. Tang, C. Dai, C. Li, W. Liu, S. Gao and C. Wang, Journal of Chemistry, 2017(4), 10(2017), https://doi.org/10.1155/2017/8404965

2. K.V. Narayana Saibaba and R.V. Kandisa, Rasayan Journal of Chemistry, 12(4), 2176(2019), https://doi.org/10.31788/RJC.2019.1245478

3. F.D. Chequer, G.A. de Oliveira, E.A. Ferraz, J.C. Cardoso, M.B. Zanoni and D.P. de Oliveira, Journal of Intech Open, 6, 151(2013), https://doi.org/10.5772/53659 
RASĀYAN J. Chem.

Vol. 14 | No. 3 |1528-1533| July - September | 2021

4. M. Khodaie, N. Ghasemi, B. Moradi and M. Rahimi, Journal of Chemistry, 2013, 6(2013), https://doi.org/10.1155/2013/383985

5. J. Cheng, C. Zhan, J. Wu, Z. Cui, J. Si, Q. Wang, X. Peng and L.S. Turng, ACS omega, 5 (10), 5389(2020), https://doi.org/10.1021/acsomega.9b04425

6. D. Pathania, S. Sharma and P. Singh, Arabian Journal of Chemistry, 10, S1445(2017), https://doi.org/10.1016/j.arabjc.2013.04.021

7. A.M. Aljebori and A.N. Alshirifi, Asian Journal of Chemistry, 24(12), 5813(2012)

8. M.N. Rashed, Journal of IntechOpen, 7, 167 (2013), https://doi.org/10.5772/54048

9. T. Aysu and M.M. Kucuk. International Journal of Environmental Science and Technology, 12(7), 2273(2015), https://doi.org/10.1007/s13762-014-0623-y

10. Ü. Geçgel, G. Özcan and G.C. Gürpınar, Journal of Chemistry, 2013, 9(2013), https://doi.org/10.1155/2013/614083

11. G.O. El-Sayed, Desalination, 272(1-3), 225(2011), https://doi.org/10.1016/j.desal.2011.01.025

12. S.P. Raghuvanshi, R Singh, C.P. Kaushik and A.K. Raghav, Applied Ecology and Environmental Research, 2(2), 35(2004), https://doi.org/10.15666/aeer/03035043

13. O.S. Bayomie, H. Kandeel, T. Shoeib, H. Yang, N. Youssef and M.M. El-Sayed, Scientific Reports, 10(1), 1(2020), https://doi.org/10.1038/s41598-020-64727-5

14. A. Said, M.S. Hakim and Y Rohyami, In Proceedings of the International Conference on Chemical, Biological, and Environmental Sciences, 11 (2014), https://doi.org/10.17758/IAAST.A0514002

15. R.V Kandisa, K.V. Narayana Saibaba, R. Gopinadh and K. Veerabhadram, Journal of Industrial Pollution Control, 34(2), 2054(2018).

16. T. Teka and S. Enyew, International Journal of Innovation and Scientific Research, 8(1), 106(2014).

17. N. Gnanasundaram, M. Loganathan and A. Singh, IOP Conference Series: Materials Science and Engineering, 206, 012065(2017), https://doi.org/10.1088/1757-899X/206/1/012065

18. H. Revathi, A. Kaviyarasu, T. Murugan, M. D. Kumar and R. S. Devi, Rasayan Journal of Chemistry, 11(4), 1415(2018), https://doi.org/10.31788/RJC.2018.1143054

19. M. A. M. Razil, M. N. Hishammudin and R Hamdan, MATEC Web of Conferences, 103, 06015(2017), https://doi.org/10.1051/matecconf/201710306015

20. H. Patel and R.T. Vashi, Journal of Chemistry, 7(4), 1468(2010), https://doi.org/10.1155/2010/987620

21. S. Rani, M. Bansal, K. Kaur and S. Sharma, Rasayan Journal of Chemistry, 12(3), 1315(2019), https://doi.org/10.31788/RJC.2019.1235279

22. M. Santhi, P. E. Kumar and M. Sathy, Rasayan Journal of Chemistry, 11(4), 1423(2018), https://doi.org/10.31788/RJC.2018.1143066

23. H. Joga Rao, P. King and Y. Prasanna Kumar, Rasayan Journal of Chemistry, 11(3), 1376(2018), https://doi.org/10.31788/RJC.2018.1134035

24. J. N. Nsami and J. Ketcha Mbadcam, Journal of Chemistry, 2013, (2013), https://doi.org/10.1155/2013/469170

25. S. Kaur, S. Rani and R. K. Mahajan, Journal of Chemistry, 2013, (2013), https://doi.org/10.1155/2013/628582

26. K. S. Padmavathy, G. Madhu and P. V. Haseena, Procedia Technology, 24, 585(2016), https://doi.org/10.1016/j.protcy.2016.05.127

27. P. M. Thabede, N. D. Shooto and E. B. Naidoo, South African Journal of Chemical Engineering, 33, 39(2020), https://doi.org/10.1016/j.sajce.2020.04.002

28. H. Koyuncu and A. Z. Kul, Applied Water Science, 10(2), 72(2020), https://doi.org/10.1007/s13201020-1156-9

29. Z. Derakhshan, M.A. Baghapour, M. Ranjba and M. Faramarzian, Health Scope, 2(3), 136(2013), https://doi.org/10.17795/jhealthscope-12492

30. L.W. Low, T. T. Teng, N. Morad and B. Azahari, APCBEE Procedia, 1, 103(2012), https://doi.org/10.1016/j.apcbee.2012.03.018

[RJC-6307/2020] 